\title{
28 Research Square \\ Polymorphisms of ATP-binding cassette, sub-family A, member 4 (rs560426 and rs481931) and non-syndromic cleft lip/palate: A systematic review and meta-analysis
}

Mohammad Moslem Imani

Kermanshah University of Medical Sciences

Mohsen Safaei

Kermanshah University of Medical Sciences

Pia Lopez-Jornet

Universidad de Murcia

Eduardo Pons-Fuster López

Universidad de Murcia

Masoud Sadeghi ( $\sim$ sadeghi_mbrc@yahoo.com )

Kermanshah University of Medical Sciences https://orcid.org/0000-0002-3586-3012

Research article

Keywords: ABCA4; Polymorphism; Variation; Non-syndromic cleft lip/palate; Meta-analysis

Posted Date: November 7th, 2019

DOI: https://doi.org/10.21203/rs.2.16984/v1

License: (c) (i) This work is licensed under a Creative Commons Attribution 4.0 International License. Read Full License 


\section{Abstract}

Background A number of gene loci are closely associated with the incidence of non-syndromic cleft lip/palate (NSCL/P). Herein, this meta-analysis assessed the association between ATP-binding cassette, sub-family A, member 4 (ABCA4) polymorphisms (rs560426 and rs481931) and the risk of NSCL/P by reviewing case-control studies.Methods Four databases including Scopus, Cochrane Library, Web of Science, and PubMed were searched for articles published up to December 2018. The Review Manager 5.3 software was used to calculate the crude odds ratio (OR) and $95 \%$ confidence interval $(\mathrm{Cl})$.Results Of 82 retrieved studies, 12 were analyzed in this meta-analysis (2,859 NSCL/P patients and 3,792 controls for ABCA4 rs560426 polymorphism and 1,333 NSCL/P patients and 1,884 controls for ABCA4 rs481931 polymorphism). There was no significant association between the polymorphisms and the risk of NSCL/P, with the exception of the allelic model (OR=1.13; $95 \% \mathrm{Cl}: 1.01,1.27 ; p=0.03)$, the homozygote model (OR=1.53; $95 \% \mathrm{Cl}$ : $1.01,2.31 ; p=0.04)$, and the recessive model (OR=1.30; $95 \% \mathrm{Cl}: 1.03,1.63 ; p=0.03)$ in the Asian ethnicity for rs 560426 polymorphism.Conclusion The findings confirmed that G allele and GG genotype of rs 560426 polymorphism were significantly associated with the risk of NSCL/P in the Asian population, but not for rs481931polymorphism. Also, there was no association between both polymorphisms (rs560426 and rs481931) with the risk of NSCL/P in the Caucasian and the mixed ethnicities, as well as the source of controls. Therefore, ethnicity may play a significant role in this association.

\section{Introduction}

Non-syndromic cleft lip/palate (NSCL/P) is a usual congenital malformation that accounts for more than $70 \%$ of facial cleft deformities [1]. Its prevalence ranges from 1/700 to 1/1000, depending on the geographical area and ethnicity [2]. NSCL/P has a multifactorial etiology and therefore both environmental and genetic risk factors can affect its incidence and prevalence [1,3]. Maternal smoking, alcohol consumption, and folic acid and vitamin deficiencies especially during the first trimester of pregnancy have been reported to increase the incidence of NSCL/P [4]. Considering the complex etiology of NSCL/P, studies have shown that interactions of gene-gene and gene-environment may be related to susceptibility to NSCL/P $[3,5,6]$. Subsequent genome-wide association studies showed that a number of gene loci are closely associated with the incidence of NSCL/P $[7,8]$. ATP-binding cassette, sub-family $\mathrm{A}$, member $4(A B C A 4)$ belongs to the transmembrane protein superfamily [9], which is located on chromosome 1p22.1 [10,11]. The ABCA4 is an ATPbinding cassette transporter that is particularly expressed in the rod and cone photoreceptor cells of the vertebrate retina [9-11] and is associated with various ocular diseases [12]. A systematic review reported the significant presence of ocular abnormalities in patients with NSCL/P [13]. The genetic basis of oral clefts is still unclear, and identification of additional risk factors for NSCL/P can greatly help in genetic counseling and may prevent the occurrence or further development of this condition [14]. Therefore, the present meta-analysis aimed to evaluate the association between ABCA4 polymorphisms (rs560426 and rs481931) and the risk of NSCL/P in case-control studies to assess the possible role of these polymorphisms in NSCL/P etiology.

\section{Materials And Methods}

The instructions of the PRISMA were applied to design this study [15]. The study was approved by the Ethics Committee of Kermanshah University of Medical Sciences, Kermanshah, Iran (ethical code: IR.KUMS.REC.1398.321).

\section{Literature search strategy}

Four electronic databases including the Web of Science, Cochrane Library, Scopus, and PubMed were searched for articles published until December 2018 without restrictions of language or publication date. The searched terms were: ("ABCA4" or "ATP-binding cassette subfamily A member 4" or "rs560426" or "rs481931") and ("cleft" or "cleft lip" or 
"cleft palate" or "orofacial cleft" or "oral cleft"). In addition, we checked the references of retrieved articles to find potential articles.

\section{Eligibility criteria}

One reviewer (M.S) retrieved the studies from the databases. Then, he excluded duplicate and irrelevant studies. The studies were relevant if they met the following eligibility criteria: (I) case-control design; (II) NSCL/P was the outcome of interest; (III) reporting $A B C A 4$ rs560426 ( $>$ $>$ ) and/or rs481931 ( $>A$ ) polymorphisms, and (IV) having the required data to calculate the odds ratios (ORs) with $95 \%$ confidence intervals (Cls). The studies were excluded if they did not have the required data regarding genotype distributions or were animal studies, review articles, letters to the editor reporting previous studies, and family-based studies. The second reviewer (M.M.I) checked the relevant articles based on the eligibility criteria. The differences between tow reviewers were solved by the third reviewer (E.P.-F.L).

\section{Data extraction}

Two reviewers (P.L.-J and M.S) independently extracted the data from each study. The information retrieved from the studies involved: the first author's name, the publication year, the ethnic group, the source of controls, the mean age, the number of males in the two groups, the type of disease, the number of patients and controls with each genotype, the genotyping method, and the $p$-value of Hardy-Weinberg equilibrium in controls. If there was a disagreement between the reviewers, the problem was solved by discussion.

\section{Quality of assessment}

One reviewer (M.M.I) distinguished the quality of each included article using the Newcastle-Ottawa Quality Assessment Scale questionnaire (maximum total score $=9$ for a case-control study) [16].

\section{Statistical analyses}

An analysis was performed by the Review Manager 5.3 using crude OR and 95\% $\mathrm{Cl}$ to show the association between $A B C A 4$ polymorphisms and the risk of NSCL/P in the five genetic models [17]. The Z test was applied to evaluate the pooled OR significance. Heterogeneity across the studies was checked by the Cochrane $\mathrm{Q}$ test and $\mathrm{I}^{2}$ statistic that there was a statistically significant heterogeneity if $P<0.1$ or $\mathrm{I}^{2}>50 \%$. If there was no significant heterogeneity, the fixedeffects model (Mantel-Haenszel method) was used to estimate the values. Otherwise, we used the random-effects model (DerSimonian and Laird method). The Chi-square test was used to calculate the Hardy-Weinberg equilibrium in the control group of each study. Subgroup analysis was done according to the ethnicity and the source of controls. The Comprehensive Meta-Analysis 2.0 was used to analysis funnel plot using the Egger's and Begg's tests and P<0.05 indicated significant existence of the publication bias. To evaluate the stability of the results, we used sensitivity analysis.

\section{Results}

\section{Study selection}

Of 82 retrieved studies, after removing duplicate and irrelevant studies, the full-texts of 21 studies were evaluated (Figure 1). Of 21 studies, nine were excluded with below reasons: three were family-based studies, three did not have the required data, two were letters to the editor reporting previous studies, and one evaluated the mothers of children. Finally, 12 studies were analyzed in this meta-analysis.

\section{Study characteristics}


Table 1 shows some features of the studies included in this meta-analysis that the studies were published from 2011 to 2018. Five studies [6,18-21] reported the risk of NSCL/P related to $A B C A 4$ polymorphisms in the Asian ethnicity, four $[5,7,14,22]$ in the mixed ethnicity, and three [23-25] in the Caucasian ethnicity. The source of controls in six studies $[14,18,19,21,23,24]$ was hospital-based while six other studies $[5-7,20,22,25]$ were population-based. Some studies reported the mean age, the number of males in the two groups, and the type of disease. Of 12 studies, all of them reported $A B C A 4$ rs560426 polymorphism, but only six studies [5,6,21,23-25] reported $A B C A 4$ rs481931 polymorphism. There were different genotyping methods among the studies presented in Table 1. The Hardy-Weinberg equilibrium was not seen in controls of two studies $[6,19]$ reporting $A B C A 4$ rs 560426 polymorphism while two studies $[6,24]$ reported $A B C A 4$ rs481931 polymorphism. This meta-analysis included 2,859 NSCL/P patients and 3,792 controls reporting $A B C A 4$ rs560426 polymorphism and 1,333 NSCL/P patients and 1,884 controls reporting ABCA4 rs481931 polymorphism.

\section{Pooled analysis}

Figure 2 shows the pooled results (combining data from each individual study included) of the risk of NSCL/P related to ABCA4 rs560426 polymorphism based on twelve studies. The heterogeneity in allelic, homozygote, heterozygote, and dominant models was high $\left(\mathrm{I}^{2}>50 \%\right)$ and therefore random-effects model was used, but in recessive model, fixedeffects model was used because of low heterogeneity $\left(\mathrm{I}^{2}<50 \%\right)$. The pooled OR was 1.01 [95\% Cl: 0.88, 1.15; $p=0.92$; $I^{2}=72 \%\left(P_{h}\right.$ or $\left.\left.P_{\text {heterogeneity }}<0.0001\right)\right]$ in the allelic model (G vs. A), $1.08\left[95 \%\right.$ Cl: $\left.0.79,1.47 ; p=0.64 ; I^{2}=77 \%\left(P_{h}<0.00001\right)\right]$ in the homozygote model (GG vs. AA), $0.93\left[95 \% \mathrm{Cl}: 0.73,1.17 ; p=0.53 ; 1^{2}=76 \%\left(P_{h}<0.00001\right)\right]$ in the heterozygote model (AG vs. AA), 0.89 [95\% Cl: 0.70, 1.14; $\left.p=0.37 ; \mathrm{I}^{2}=81 \%\left(\mathrm{P}_{\mathrm{h}}<0.00001\right)\right]$ in the dominant model $(\mathrm{AG}+\mathrm{GG}$ vs. $A \mathrm{~A})$, and 1.08 [95\% Cl: $\left.0.91,1.26 ; p=0.38 ; I^{2}=36 \%\left(P_{h}=0.10\right)\right]$ in the recessive model (GG vs. AA + AG). Based on the genetic models, there was no the risk of NSCL/P related to ABCA4 rs560426 polymorphism.

The pooled results of the significant risk of NSCL/P related to $A B C A 4$ rs481931 polymorphism according to six studies is shown in Figure 3. The heterogeneity in all analyses was low and therefore fixed-effects model was used $\left(I^{2}<50 \%\right)$. The pooled OR was 0.92 [95\% Cl: 0.83, 1.02; $\left.p=0.12 ;\left.\right|^{2}=35 \%\left(P_{h}=0.17\right)\right]$ in the allelic model (A vs. C), 0.85 [95\%Cl: 0.68 , $\left.1.05 ; p=0.13 ; I^{2}=33 \%\left(P_{h}=0.19\right)\right]$ in the homozygote model (AA vs. CC), $0.88\left[95 \% \mathrm{Cl}: 0.75,1.03 ; p=0.12 ; I^{2}=16 \%\left(P_{h}=0.31\right)\right]$ in the heterozygote model (CA vs. CC), 0.87 [95\% Cl: 0.75, 1.00; $p=0.06 ; I^{2}=29 \%\left(P_{h}=0.22\right)$ ] in the dominant model (CA + AA vs. CC), and $0.89\left[95 \% \mathrm{Cl}: 0.74,1.09 ; p=0.26 ; \mathrm{I}^{2}=22 \%\left(\mathrm{P}_{\mathrm{h}}=0.27\right)\right]$ in the recessive model (AA vs. CC $\left.+\mathrm{CA}\right)$. Based on the genetic models, there was no the significant risk of NSCL/P related to $A B C A 4$ rs481931 polymorphism.

\section{Subgroup analysis}

The first subgroup analysis evaluated the pooled analysis based on the ethnicity and the source of controls for the significant risk of NSCL/P related to ABCA4 rs560426 polymorphism (Table 2) that there was only a significant risk in the Asian ethnicity based on the allelic model (OR=1.13; $95 \% \mathrm{Cl}: 1.01,1.27 ; p=0.03)$, the homozygote model (OR=1.53; $95 \% \mathrm{Cl}: 1.01,2.31 ; p=0.04)$, and the recessive model (OR=1.30; $95 \% \mathrm{Cl}: 1.03,1.63 ; p=0.03)$. The results didn't show the risk of NSCL/P related to in rs560426 polymorphism in the Caucasian and the mixed ethnicities, as well as the studies including hospital-based and population-based controls based on the models.

The second subgroup analysis assessed the risk of NSCL/P related to $A B C A 4$ rs481931 polymorphism according to the ethnicity and the source of controls (Table 3). There was no association between the significant risk of NSCL/P and rs481931 polymorphism in the Asian, the Caucasian, and the mixed ethnicities, as well as the studies including hospital-based and population-based controls based on the models. 


\section{Sensitivity analysis}

One study was removed and the cumulative analysis identified that the pooled ORs under all genetic models were stable and trustworthy. As well as, excluding two studies $[6,19]$ that had $p$-values $<0.05$ for Hardy-Weinberg equilibrium in controls did not change the overall result regarding the risk of NSCL/P related to $A B C A 4$ rs560426 polymorphism. Excluding two other studies[6,24] did not change the overall result regarding the risk of NSCL/P related to $A B C A 4$ rs481931 polymorphism.

\section{Quality assessment}

A mean score of 7.33 was achieved for the quality of all studies (Table 4). Out of 12 studies, ten studies had score $\geq 7$ and two studies had score $<7$.

\section{Publication bias}

Figure 4 shows the funnel plot of the association between $A B C A 4$ polymorphisms and the risk of NSCL/P using the five genetic models. The Egger's and Begg's tests did not reveal any publication bias except for 4 states: Both tests for A vs. $C$ and $A A$ vs. CC revealed a publication bias and Egger's test for CA vs. CC and CA + AA vs. CC revealed a publication bias $(p<0.05)$.

\section{Discussion}

The $A B C A 4$ gene mutations have been associated with a range of autosomal recessive retinal degenerative diseases [24]. NSCL/P is a complex congenital anomaly that shows both clinical and genetic heterogeneity and the genetic basis of NSCL/P have remained unclear [14]. Among the studies reviewed in this meta-analysis, the rs560426 $\mathrm{G}$ allele showed 1.36- [21] and 1.34-fold [22] increase in the risk of CL/P compared to the A allele and the rs560426 GG genotype showed 1.74- [19], 3- [20], 1.86- [21], and 1.72-fold [22] increase in the risk of NSCL/P compared to the AA genotype. In contrast, the $\mathrm{G}$ allele, GG genotype [23], AG genotype [5,23], A allele [23], AA genotype [24], and CA genotype [23] showed a lower risk of NSCL/P compared to the A allele, AA genotype, AA genotype, $\mathrm{C}$ allele, $\mathrm{C}$ genotype, and $\mathrm{CC}$ genotype, respectively. This meta-analysis did not exhibit any significant risk of NSCL/P related to ABCA4 polymorphisms (rs560426 and rs481931) except for the Asian ethnicity in which, the G allele and GG genotype identified a significant increase in the risk of NSCL/P compared to A allele and AA genotype, respectively. In addition to some studies mentioned in this meta-analysis, which indicated a link between the ABCA4 gene and the NSCL/P risk, associations of this gene with CL/P in two genome-wide association studies [26,27] and in different populations [28-30] highlight the need for further studies on the possible role of $A B C A 4$ gene in the CL/P etiology. Fontoura et al.[23] found significant associations of ABCA4 rs481931 alleles with bilateral and unilateral CL/P. Replication of $A B C A 4$ polymorphisms using independent families from various populations revealed that the Asian families had stronger evidence for $A B C A 4$ compared to the European or American families [19]. The present meta-analysis confirmed this result.

One study [18] suggested that the strong correlation between $A B C A 4$ and CL/P may be due to the impact of nearby genes (such as $A R H G A P 29$ ), and not the impact of single loci. It is probably that the associated variants in $A B C A 4$ are in close connection disequilibrium with a causal variant included in a neighboring gene, and act as indirect surrogates for a real etiologic variant in NSCL/P patients $[23,24,29]$. Gene-gene and gene-environment interactions showed that there was an interaction between $A B C A 4$ rs 560426 polymorphism with folic acid consumption and V-maf avian musculoaponeurotic fibrosarcoma oncogene homolog B rs11696257 polymorphism [5]. The different rate of the $G$ allele of rs 560426 polymorphism in different populations shows that the polymorphism alone is not associated with NSCL/P development, and so, it may not be the causative single-nucleotide polymorphism. Therefore, this apparent incompatibility among populations may identify the complex genetic etiology of NSCL/P [21]. The transmission 
analysis using case-parent core pedigrees showed that the $C$ allele of rs481931 was significantly over-transmitted from parents to children, indicating that the $C$ allele is associated with the NSCL/P risk. In addition, the C (rs481931)-G (rs560426) haplotype was significantly involved in the occurrence of NSCL/P [6].

The present meta-analysis had several limitations: a small number of studies reviewed, differences in age and sex of patients and genotyping methods, absence of Hardy-Weinberg equilibrium in some studies, a difference of sources of controls and ethnicities evaluated in the studies that created high heterogeneity in some analyses. However, sensitivity analysis identified the stability of the results and also the heterogeneity across the studies was minimal.

\section{Conclusions}

The findings of the present meta-analysis confirmed that the $\mathrm{G}$ allele and $\mathrm{GG}$ genotype of rs 560426 polymorphism were significantly associated with the NSCL/P risk in the Asian population. There was no association between both

polymorphisms (rs560426 and rs481931) with the risk of NSCL/P in the Caucasian and the mixed ethnicities, as well as the source of controls and even the Asian ethnicity for rs481931polymorphism. Therefore, ethnicity may act as a significant factor in this association. Nevertheless, further studies are needed to check the association of different ethnic groups with special emphasis on the interactions of the $A B C A 4$ gene.

\section{Abbreviations}

NSCL/P: Non-syndromic cleft lip/palate

ABCA4: ATP-binding cassette, sub-family A, member 4

OR: Odds ratio

Cl: Confidence interval

\section{Declarations}

\section{Ethics approval and consent to participate}

The study was approved by the Ethics Committee of Kermanshah University of Medical Sciences, Kermanshah, Iran (ethical code: IR.KUMS.REC.1398.321).

\section{Consent for publication}

Not applicable.

\section{Availability of data and materials}

The datasets used and/or analyzed during the current study available from the corresponding author on reasonable request.

\section{Competing interests}

The authors declare that they have no competing interests.

\section{Funding}

This work was supported by Kermanshah University of Medical Sciences, Kermanshah, Iran (Grant number: 3008230). 


\section{Authors' Contributions}

M.M.I and Ma.S: study design, study concept, analysis of images, statistical analysis, data collection, data interpretation, coordination of the study, literature search. P.L.-J, Mo.S, and E.P.-F.L: critically revised and edited the manuscript before submission and coordination of the study. Ma.S: drafted the manuscript. All authors read and approved the final manuscript.

\section{Acknowledgements}

Not applicable.

\section{References}

1. Mossey PA, Little J, Munger RG, Dixon MJ, Shaw WC. Cleft lip and palate. Lancet. 2009;374:1773-85. 2. Mossey PA, Modell B. Epidemiology of oral clefts 2012: an international perspective. Front Oral Biol. 2012;16:1-18. 3. Dixon MJ, Marazita ML, Beaty, TH, Murray JC. Cleft lip and palate: understanding genetic and environmental influences. Nat Rev Genet. 2011;12:167-8. 4. Bezerra JF, Oliveira GH, Soares CD, Cardoso ML, Ururahy MA, Neto FP, et al. Genetic and nongenetic factors that increase the risk of non-syndromic cleft lip and/or palate development. Oral Dis. 2015;21:393-9. 5. Velázquez-Aragón JA, Alcántara-Ortigoza MA, Estandia-Ortega B, Reyna-Fabián ME, Méndez-Adame CD, González-Del Angel A. Gene Interactions Provide Evidence for Signaling Pathways Involved in Cleft Lip/Palate in Humans. J Dent Res. 2016;95:1257-64. 6. Wu N, Lu Y, Liu K, Li Z, Liu Q, Lu L. Associations of ABCA4 and MAFB with Nonsyndromic Cleft Lip with or without Cleft Palate in a Northeastern Chinese Population. J Hard Tissue Biol. 2018;27:181-4. 7. Ludwig KU, Wahle P, Reutter H, Paredes-Zenteno M, Muñoz-Jimenez SG, Ortiz-Lopez R, et al. Evaluating eight newly identified susceptibility loci for nonsyndromic cleft lip with or without cleft palate in a Mesoamerican population. Birth Defects Res A Clin Mol Teratol. 2014;100:43-7. 8. Böhmer AC, Gölz L, Kreusch T, Kramer FJ, Pötzsch B, Nöthen MM, et al. Investigation of dominant and recessive inheritance models in GWAS data ofnonsyndromic cleft lip with or without cleft palate. Birth Defects Res. 2018;110:336-41. 9. Molday RS, Zhong M, Quazi F. The role of the photoreceptor ABC transporter ABCA4 in lipid transport and Stargardt macular degeneration. Biochim Biophys Acta. 2009;1791:573-83. 10. Sun H, Molday RS, Nathans J. Retinal stimulates ATP hydrolysis by purified and reconstituted ABCR, the photoreceptorspecific ATP-binding cassette transporter responsible for Stargardt disease. J Biol Chem 1999;274:8269-81. 11. Cideciyan AV, Swider M, Aleman TS, Tsybovsky Y, Schwartz SB, Windsor EA, et al. ABCA4 disease progression and a proposed strategy for gene therapy. Hum Molec Genet. 2009;18:931-41. 12. Burton DS, Ali M, McKibbin M. Retinal phenotypes in patients homozygous for the G1961E mutation in the ABCA4 gene. Invest Ophthalmol Vis Sci. 2013;54:520. 13. Luciano Sólia N, Daniella Reis Barbosa M, Mário Sérgio Oliveira S, Daniela Araújo Veloso P, Letízia Monteiro de B, Hercílio MJ. Ophthalmic changes in cleft lip and palate. Rev Bras Talmol. 2016;75:94-8. 14. do Rego Borges A1, Sá J, Hoshi R, Viena CS, Mariano LC, de Castro Veiga P, et al. Genetic risk factors for nonsyndromic cleft lip with or without cleft palate in a Brazilian population with high African ancestry. Am J Med Genet A. 2015;167A:23442349. 15. Moher D, Liberati A, Tetzlaff J, Altman DG, The PRISMA Group. Preferred Reporting Items for Systematic Reviews and Meta-Analyses: The PRISMA Statement. PLoS Med. 2009;6:e1000097. 16. Wells GA, Shea B, O'Connell D, Robertson J, Peterson J, Welch V, et al. The Newcastle-Ottawa scale (NOS) for assessing the quality of non-randomised studies in meta-analyses. Ottawa: Ottawa Hospital Research Institute. 2011.

http://www.ohri.ca/programs/clinical_epidemiology/oxford.asp. Accessed 12 Jan 2016. 17. Lei S, Huang L, Liu Y, Xu L, Wang D, Yang L. Association between polymorphisms of heat-shock protein 70 genes and noise-induced hearing loss: $A$ meta-analysis. PLoS One. 2017;12:e0188539. 18. Pan Y, Zhang W, Du Y, Tong N, Han Y, Zhang H, et al. Different roles of two novel susceptibility loci for nonsyndromic orofacial clefts in a Chinese Han population. Am J Med Genet A. 2011;155A:2180-5. 19. Huang E, Cheng H, Xu M, Shu S, Tang S. Association between single-nucleotide polymorphisms on chromosome 1p22 and 20q12 and nonsyndromic cleft lip with or without cleft palate: new data in Han Chinese and 
meta-analysis. Birth Defects Res A Clin Mol Teratol. 2012;94:469-76. 20. Zhong-wei Z, Xiong Y, Ying-biao W, Yan-hua X, Kun Z, Jian M, et al. Associations of chromosomes 17q22, 10q25.3 and ABCA4 gene polymorphisms with nonsyndromic cleft lip/palate in Ningxia Hui and Han population. J Shandong Univ. 2013;51:103-108. 21. Mi N, Hao Y, Jiao $X$, Zheng X, Shi J, Chen Y. A polymorphic marker associated with non-syndromic cleft lip with or without cleft palate in a population in Heilongjiang Province, northern China. Arch Oral Biol 2015;60:357-61. 22. Bagordakis E, Paranaiba LM, Brito LA, de Aquino SN, Messetti AC, Martelli-Junior H, et al. Polymorphisms at regions 1p22.1 (rs560426) and 8q24 (rs1530300) are risk markers for nonsyndromic cleft lip and/or palate in the Brazilian population. Am J Med Genet A. 2013; 161A:1177-1180. 23. Fontoura C, Silva RM, Granjeiro JM, Letra A. Further evidence of association of the ABCA4 gene with cleft lip/palate. Eur J Oral Sci. 2012;120:553-7. 24. Mostowska A, Hozyasz KK, Wojcicka K, Biedziak B, Jagodzinski PP. Polymorphic variants at 10q25.3 and 17q22 loci and the risk of non-syndromic cleft lip and palate in the Polish population. Birth Defects Res A Clin Mol Teratol. 2012;94:42-6. 25. Babu Gurramkonda V, Hussain Syed A, Murthy J, Chaubey G, Bhaskar, Lakkakula VK. Polymorphic variants near 1p22 and 20q11.2 loci and the risk of nonsyndromic cleft lip and palate in South Indian population. Int J Pediatr Otorhinolaryngol. 2015;79:2389-93. 26. Beaty TH, Murray JC, Marazita ML, Munger RG, Ruczinski I, Hetmanski JB, et al. A genome-wide association study of cleft lip with and without cleft palate identifies risk variants near MAFB and ABCA4. Nat Genet. 2010;42:525-9. 27. Weng J, Mata NL, Azarian SM, Tzekov RT, Birch DG, Travis GH. Insights into the function of Rim protein in photoreceptors and etiology of Stargardt's disease from the phenotype in Abcr knockout mice. Cell.1999;98:13-23. 28. Yuan Q, Blanton SH, Hecht JT. Association of ABCA4 and MAFB with non-syndromic cleft lip with or without cleft palate. Am J Med Genet A 2011;155A:1469-71. 29. Lennon CJ, Birkeland AC, Nuñez JA, Su GH, Lanzano P, Guzman E, et al. Association of candidate genes with nonsyndromic clefts in Honduran and Colombian populations. Laryngoscope. 2012;122:2082-7. 30. Peng HH, Chang NC, Chen KT, Lu JJ, Chang PY, Chang SC, et al. Nonsynonymous variants in MYH9 and ABCA4 are the most frequent risk loci associated with nonsyndromic orofacial cleft in Taiwanese population. BMC Med Genet. $2016 ; 17: 59$.

\section{Tables}

Table 1: Characteristics of the studies included in this meta-analysis $(n=12)$ 


\begin{tabular}{|c|c|c|c|c|c|c|c|c|c|c|c|}
\hline \multirow{2}{*}{$\begin{array}{l}\text { First } \\
\text { author, } \\
\text { (year) }\end{array}$} & \multirow{2}{*}{$\begin{array}{l}\text { Ethnic } \\
\text { group }\end{array}$} & \multirow{2}{*}{$\begin{array}{c}\text { Source } \\
\text { of } \\
\text { controls }\end{array}$} & \multirow{2}{*}{$\begin{array}{c}\text { Mean } \\
\text { age, } \\
\text { year } \\
\text { (NSCL/P } \\
\text { to } \\
\text { control) }\end{array}$} & \multirow{2}{*}{$\begin{array}{c}\text { No. of } \\
\text { males, } \\
\text { (NSCL/P } \\
\text { to } \\
\text { control) }\end{array}$} & \multirow{2}{*}{$\begin{array}{c}\text { Type of } \\
\text { disease } \\
\text { (number } \\
\text { of } \\
\text { patients) } \\
\text { CLO/CLP }\end{array}$} & \multicolumn{2}{|c|}{ NSCL/P } & \multicolumn{2}{|c|}{ Control } & \multirow{2}{*}{$\begin{array}{c}\text { Genotyping } \\
\text { method }\end{array}$} & \multirow{2}{*}{$\begin{array}{c}\text { P-value } \\
\text { for HWE } \\
\text { in } \\
\text { controls }\end{array}$} \\
\hline & & & & & & $\mathrm{AA} / \mathrm{AG} / \mathrm{GG}$ & $\mathrm{CC} / \mathrm{CA} / \mathrm{AA}$ & $\mathrm{AA} / \mathrm{AG} / \mathrm{GG}$ & $\mathrm{CC} / \mathrm{CA} / \mathrm{AA}$ & & \\
\hline $\begin{array}{l}\text { Pan et al. } \\
\text { (2011) [18] }\end{array}$ & Asian & $\mathrm{HB}$ & $\begin{array}{c}5.54 \text { to } \\
5.49 \\
\end{array}$ & 246 to 242 & $174 / 197$ & $145 / 175 / 51$ & $\mathrm{NA}$ & $167 / 160 / 57$ & $\mathrm{NA}$ & TaqMan & 0.071 \\
\hline $\begin{array}{l}\text { Fontoura et } \\
\text { al. (2012) } \\
{[23]}\end{array}$ & Caucasian & Нв & $\begin{array}{c}17.3 \text { to } \\
24.8\end{array}$ & 252 to 165 & $\mathrm{NA}$ & $116 / 118 / 86$ & $184 / 155 / 44$ & $74 / 203 / 123$ & $154 / 192 / 57$ & TaqMan & $0.542 / 0.818$ \\
\hline $\begin{array}{l}\text { Huang et al. } \\
\text { (2012) [19] }\end{array}$ & Asian & нв & $\mathrm{NA}$ & 169 to 203 & $69 / 231$ & $135 / 126 / 39$ & $\mathrm{NA}$ & $157 / 171 / 26$ & NA & $\begin{array}{l}\text { MALDI-TOF MS } \\
\text { (Sequenom) }\end{array}$ & 0.024 \\
\hline $\begin{array}{l}\text { Mostowska et } \\
\text { al. (2012) } \\
\text { [24] }\end{array}$ & Caucasian & нв & $\mathrm{NA}$ & $\mathrm{NA}$ & $-/ 206$ & $62 / 105 / 39$ & $79 / 98 / 29$ & $120 / 230 / 96$ & $156 / 196 / 94$ & PCR-HRM & $0.467 / 0.028$ \\
\hline $\begin{array}{l}\text { Bagordakis } \\
\text { et al. (2013) } \\
{[22]} \\
\end{array}$ & Mixed & $\mathrm{PB}$ & $\mathrm{NA}$ & $\mathrm{NA}$ & $105 / 194$ & $74 / 140 / 85$ & $\mathrm{NA}$ & $127 / 172 / 85$ & NA & Multiplex PCR & 0.067 \\
\hline $\begin{array}{l}\text { Zhong-wei et } \\
\text { al. (2013) } \\
\text { [20] }\end{array}$ & Asian & $\mathrm{PB}$ & $\mathrm{NA}$ & $\mathrm{NA}$ & $69 / 112$ & $54 / 91 / 36$ & $\mathrm{NA}$ & $36 / 50 / 18$ & $\mathrm{NA}$ & TaqMan & 0.928 \\
\hline $\begin{array}{l}\text { Ludwig et al. } \\
\text { (2014) [7] }\end{array}$ & Mixed & РB & NA & 102 to 111 & $\mathrm{NA}$ & $37 / 73 / 33$ & $\mathrm{NA}$ & $100 / 163 / 66$ & $\mathrm{NA}$ & $\begin{array}{l}\text { MALDI-TOF MS } \\
\text { (Sequenom) }\end{array}$ & 0.977 \\
\hline $\begin{array}{l}\text { do Rego } \\
\text { Borges et al. } \\
\text { (2015) [14] } \\
\end{array}$ & Mixed & нв & $\mathrm{NA}$ & $\mathrm{NA}$ & $86 / 207$ & $76 / 152 / 65$ & NA & $74 / 187 / 91$ & $\mathrm{NA}$ & TaqMan & 0.223 \\
\hline $\begin{array}{l}\text { Babu } \\
\text { Gurramkonda } \\
\text { et al. (2015) } \\
\text { [25] }\end{array}$ & Caucasian & $\mathrm{PB}$ & $\mathrm{NA}$ & $\mathrm{NA}$ & $\mathrm{NA}$ & $46 / 72 / 26$ & $41 / 68 / 35$ & $61 / 80 / 35$ & $57 / 87 / 32$ & $\begin{array}{l}\text { Kompetitive } \\
\text { allele specific } \\
\text { PCR (KASP) }\end{array}$ & $0.348 / 0.905$ \\
\hline $\begin{array}{l}\text { Mi et al. } \\
\text { (2015) [21] }\end{array}$ & Asian & HB & $\begin{array}{c}4.98 \text { to } \\
5.20\end{array}$ & $\mathrm{NA}$ & $\mathrm{NA}$ & $88 / 104 / 30$ & 79/107/36 & $158 / 137 / 29$ & $113 / 157 / 54$ & $\begin{array}{c}\text { Mini- } \\
\text { sequencing } \\
\text { (SNAPSHOT) }\end{array}$ & $0.928 / 0.965$ \\
\hline $\begin{array}{l}\text { Velázquez- } \\
\text { Aragón et al. } \\
\text { (2016) [5] }\end{array}$ & Mixed & $\mathrm{PB}$ & 5.5 to 1.33 & 99 to 132 & $\mathrm{NA}$ & $44 / 56 / 32$ & $32 / 71 / 27$ & $54 / 137 / 68$ & $71 / 131 / 53$ & $\begin{array}{l}\text { Kompetitive } \\
\text { allele specific } \\
\text { PCR (KASP) }\end{array}$ & $0.326 / 0.602$ \\
\hline $\begin{array}{l}\text { Wu et al. } \\
\text { (2018) [6] }\end{array}$ & Asian & $\mathrm{PB}$ & NA & NA & $\mathrm{NA}$ & $103 / 116 / 29$ & $92 / 126 / 30$ & $111 / 145 / 24$ & $91 / 154 / 35$ & PCR-RFLP & $0.014 / 0.015$ \\
\hline
\end{tabular}

Abbreviations: MALDI-TOF MS, Matrix-assisted laser desorption/ionization time-of-flight mass spectrometry; PCR-HRM, polymerase chain reaction; HRM, high resolution melting, RFLP, restriction fragment length polymorphism, CLO, cleft lip only; CLP, cleft lip and palate; NSCL/P, non-syndromic cleft lip/palate; HB, hospital-based; PB, population-based; HWE, HardyWeinberg equilibrium, NA, not available.

Table 2: Analysis of non-syndromic cleft lip/palate risk related to rs560426 polymorphism according to ethnicity and source of controls 


\begin{tabular}{|c|c|c|c|c|c|}
\hline \multirow[t]{2}{*}{ Study (n) } & G vs. A & GG vs. AA & AG vs. AA & $A G+G G$ vs. $A A$ & GG vs. AA + AG \\
\hline & OR $(95 \% C I), I^{2}(\%), P_{h}$ & OR $(95 \% C I), I^{2}(\%), P_{h}$ & OR $(95 \% C I), I^{2}(\%), P_{h}$ & OR $(95 \% C I), I^{2}(\%), P_{h}$ & $\begin{array}{c}\text { OR (95\%CI), } \mathrm{I}^{2}(\%) \text {, } \\
\mathrm{P}_{\mathrm{h}}\end{array}$ \\
\hline Overall (12) & $\begin{array}{c}1.01(0.88,1.15), 72 \\
<0.0001\end{array}$ & $\begin{array}{c}1.08(0.79,1.47), 77 \\
<0.00001\end{array}$ & $\begin{array}{c}0.93(0.73,1.16), 76 \\
<0.00001\end{array}$ & $\begin{array}{c}0.89(0.70,1.14), 81 \\
<0.00001\end{array}$ & $\begin{array}{c}1.08(0.91,1.26) \\
36,0.10\end{array}$ \\
\hline \multicolumn{6}{|l|}{ Ethnicity } \\
\hline Asian (5) & $\begin{array}{c}1.13(1.01,1.27), 0 \\
0.59\end{array}$ & $\begin{array}{c}1.53(1.01,2.31), 62 \\
0.03\end{array}$ & $\begin{array}{c}1.08(0.92,1.26), 35 \\
0.19\end{array}$ & $\begin{array}{c}1.13(0.97,1.32), 10 \\
0.35\end{array}$ & $\begin{array}{c}1.30(1.03,1.63) \\
27,0.24\end{array}$ \\
\hline Caucasian (3) & $\begin{array}{c}0.82(0.63,1.08), 71 \\
0.03\end{array}$ & $\begin{array}{c}0.67(0.42,1.09), 64 \\
0.06\end{array}$ & $\begin{array}{c}0.72(0.36,1.45), 88 \\
0.0002\end{array}$ & $\begin{array}{c}0.55(0.34,0.88), 79 \\
0.009\end{array}$ & $\begin{array}{c}0.85(0.67,1.07), 0, \\
0.98\end{array}$ \\
\hline Mixed (4) & $\begin{array}{c}1.00(0.76,1.31), 79 \\
0.003\end{array}$ & $\begin{array}{c}0.99(0.59,1.68), 78 \\
0.004\end{array}$ & $\begin{array}{c}0.92(0.60,1.42), 76 \\
0.006\end{array}$ & $\begin{array}{c}0.94(0.60,1.49), 81 \\
0.001\end{array}$ & $\begin{array}{c}1.07(0.87,1.30) \\
41,0.17\end{array}$ \\
\hline \multicolumn{6}{|l|}{$\begin{array}{l}\text { Source of } \\
\text { controls }\end{array}$} \\
\hline $\begin{array}{l}\text { Hospital-based } \\
\text { (6) }\end{array}$ & $\begin{array}{c}0.94(0.86,1.03), 80 \\
0.0001\end{array}$ & $\begin{array}{c}0.83(0.69,1.01), 80 \\
0.0002\end{array}$ & $\begin{array}{c}0.87(0.76,1.01), 84 \\
\quad<0.00001\end{array}$ & $\begin{array}{c}0.89(0.78,1.02), 85 \\
<0.00001\end{array}$ & $\begin{array}{c}0.98(0.83,1.15) \\
57,0.04\end{array}$ \\
\hline $\begin{array}{l}\text { Population- } \\
\text { based (6) }\end{array}$ & $\begin{array}{c}1.07(0.91,1.26), 52 \\
0.06\end{array}$ & $\begin{array}{c}1.29(0.86,1.94), 66 \\
0.01\end{array}$ & $\begin{array}{c}1.02(0.76,1.36), 60 \\
0.03\end{array}$ & $\begin{array}{c}0.91(0.62,1.33), 80 \\
0.0002\end{array}$ & $\begin{array}{c}1.18(0.97,1.44), 0, \\
0.63\end{array}$ \\
\hline
\end{tabular}

Bold numbers mean statistically significant $(\mathrm{P}<0.05) . \mathrm{P}_{\mathrm{h}}$ indicates $\mathrm{P}$ heterogeneity. Abbreviations: OR, odds ratio; CI, confidence interval.

Table 3: Analysis of non-syndromic cleft lip/palate risk related to rs481931 polymorphism according to ethnicity and source of controls

\begin{tabular}{|c|c|c|c|c|c|}
\hline \multirow[t]{2}{*}{ Study (n) } & A vs. C & AA vs. CC & CA vs. CC & $\mathrm{CA}+\mathrm{AA}$ vs. CC & AA vs. CC + CA \\
\hline & OR $(95 \%$ CI $), I^{2}(\%), \mathrm{P}_{\mathrm{h}}$ & OR $(95 \% C I), I^{2}(\%), P_{h}$ & OR $(95 \% C I), I^{2}(\%), P_{h}$ & OR $(95 \% C I), I^{2}(\%), P_{h}$ & OR (95\%CI), I I (\%), $\mathrm{P}_{\mathrm{h}}$ \\
\hline Overall (6) & $\begin{array}{c}0.92(0.83,1.02), 35 \\
0.17\end{array}$ & $\begin{array}{c}0.85(0.68,1.05), 33 \\
0.19\end{array}$ & $\begin{array}{c}0.88(0.75,1.03), 16 \\
0.31\end{array}$ & $\begin{array}{c}0.87(0.75,1.00), 0.29 \\
0.22\end{array}$ & $\begin{array}{c}0.89(0.74,1.09), 22 \\
0.27\end{array}$ \\
\hline \multicolumn{6}{|l|}{ Ethnicity } \\
\hline Asian (2) & $\begin{array}{l}0.94(0.79,1.12), 0, \\
0.65\end{array}$ & $\begin{array}{l}0.90(0.62,1.32), 0, \\
0.76\end{array}$ & $\begin{array}{l}0.89(0.68,1.16), 0 \\
0.49\end{array}$ & $0.89(0.69,1.15), 0,0.51$ & $\begin{array}{l}0.97(0.68,1.36), 0, \\
0.99\end{array}$ \\
\hline Caucasian (3) & $\begin{array}{l}0.92(0.71,1.18), 68 \\
0.04\end{array}$ & $\begin{array}{l}0.81(0.48,1.36), 67 \\
0.05\end{array}$ & $\begin{array}{l}0.83(0.67,1.03), 46 \\
0.15\end{array}$ & $\begin{array}{l}0.85(0.62,1.16), 56 \\
0.11\end{array}$ & $\begin{array}{l}0.87(0.55,1.38), 66 \\
0.05\end{array}$ \\
\hline Mixed (1) & $1.07(0.79,1.44)$ & $1.13(0.61,2.11)$ & $1.20(0.72,2.00)$ & $1.18(0.73,1.92)$ & $1.00(0.59,1.68)$ \\
\hline \multicolumn{6}{|l|}{ Source of controls } \\
\hline $\begin{array}{l}\text { Hospital-based } \\
\text { (2) }\end{array}$ & $\begin{array}{l}0.85(0.67,1.09), 57 \\
0.13\end{array}$ & $\begin{array}{l}0.77(0.55,1.07), 21 \\
0.26\end{array}$ & $\begin{array}{l}0.80(0.56,1.14), 55 \\
0.14\end{array}$ & $\begin{array}{l}0.79(0.55,1.14), 61 \\
0.11\end{array}$ & $\begin{array}{l}0.86(0.63,1.18), 0, \\
0.52\end{array}$ \\
\hline $\begin{array}{l}\text { Population-based } \\
\text { (4) }\end{array}$ & $\begin{array}{l}0.98(0.86,1.12), 11 \\
0.34\end{array}$ & $\begin{array}{l}0.91(0.68,1.20), 47 \\
0.13\end{array}$ & $\begin{array}{l}0.97,(0.79,1.20), 0, \\
0.62\end{array}$ & $0.95(0.78,1.16), 0,0.44$ & $\begin{array}{l}0.91(0.71,1.17), 49 \\
0.12\end{array}$ \\
\hline
\end{tabular}

There was the $p$-value $>0.05$ in all analyses and $\mathrm{P}_{\mathrm{h}}$ indicates $\mathrm{P}_{\text {heterogeneity }}$. Abbreviations: OR, odds ratio; CI, confidence interval.

Table 4: Quality assessment scores for the studies included in this meta-analysis $(n=12)$ 


\begin{tabular}{lcccc}
\hline First author, (year) & Selection & Comparability & Exposure & Total points \\
\hline Pan et al. (2011) [18] & $* * *$ & $* *$ & $* * *$ & 8 \\
Fontoura et al. (2012) [23] & $* * *$ & - & $* * *$ & 6 \\
Huang et al. (2012) [19] & $* * *$ & $*$ & $* * *$ & 7 \\
Mostowska et al. (2012) [24] & $* * *$ & $* *$ & $* * *$ & 8 \\
Bagordakis et al. (2013) [22] & $* * * *$ & - & $* * *$ & 7 \\
Zhong-wei et al. (2013) [20] & $* * * *$ & - & $* * *$ & 7 \\
Ludwig et al. (2014) [7] & $* * * *$ & - & $* * *$ & 7 \\
do Rego Borges et al. (2015) [14] & $* * *$ & - & $* * *$ & 6 \\
Babu Gurramkonda et al. (2015) [25] & $* * * *$ & $* *$ & $* * *$ & 9 \\
Mi et al. (2015) [21] & $* * *$ & $* *$ & $* * *$ & 8 \\
Velázquez-Aragón et al. (2016) [5] & $* * * *$ & $*$ & $* * *$ & 8 \\
Wu et al. (2018) [6] & $* * * *$ & - & $* * *$ & 7 \\
\hline
\end{tabular}

Each asterisk indicates one point.

\section{Figures}




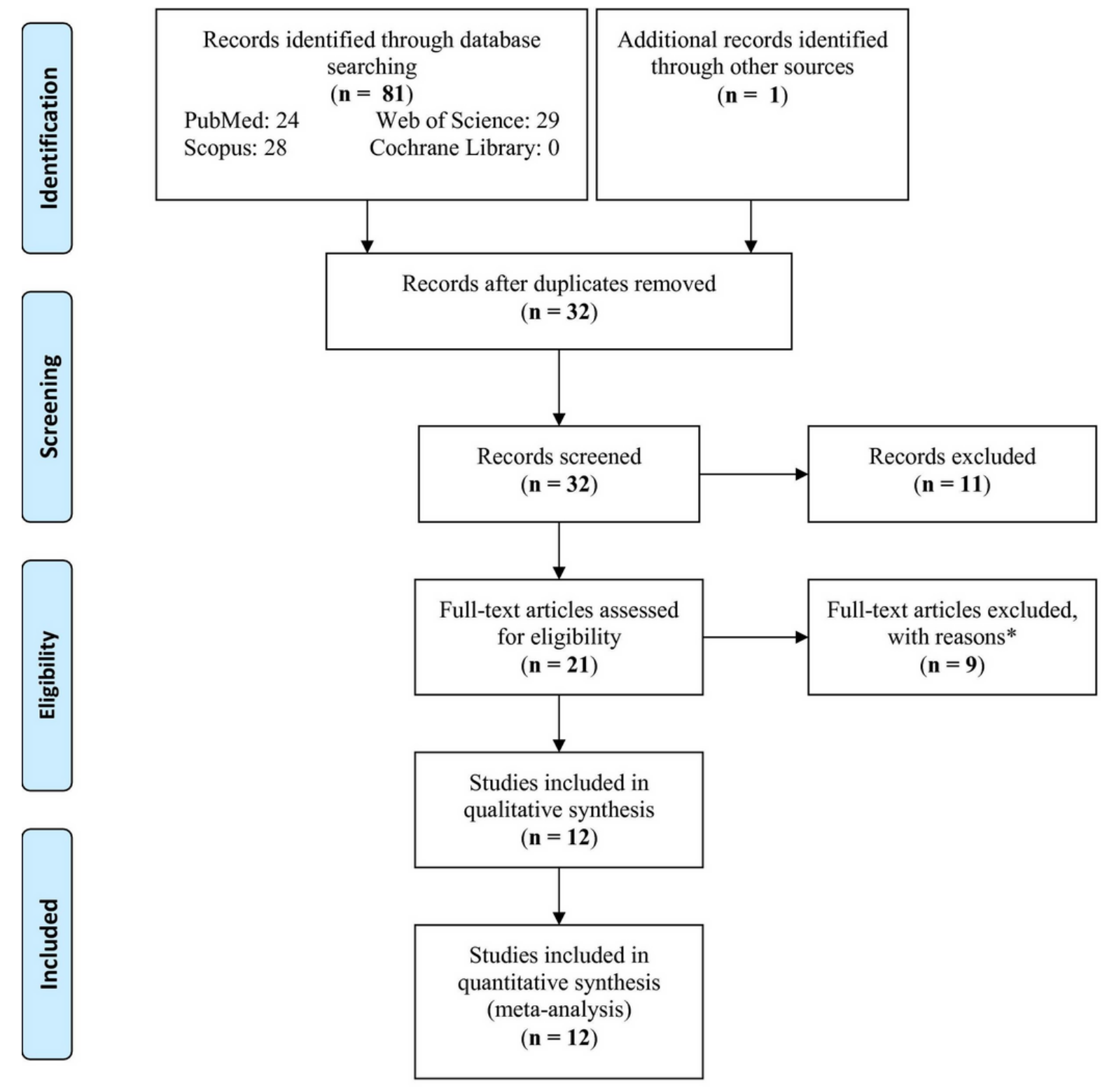

* $\underline{3}$ articles were family-based studies. $\underline{3}$ articles had no required information/data. $\underline{2}$ articles were letter to the editor related to previous studies. 1 article included mothers of children.

Figure 1

PRISMA flow-chart of the study selection 


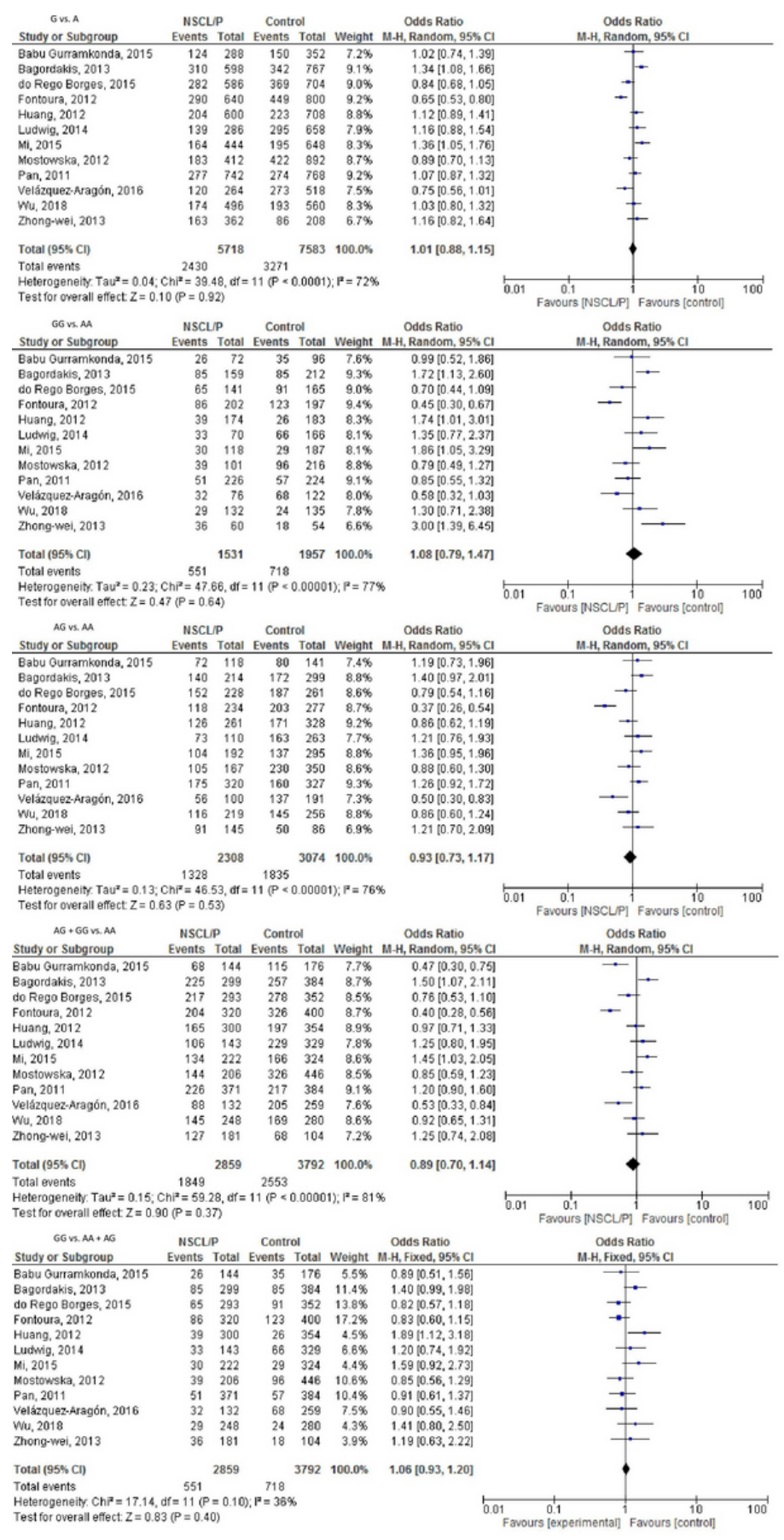

\section{Figure 2}

Forest plot of NSCL/P risk related to ABCA4 rs560426 polymorphism using the five genetic models. Abbreviation: NSCL/P, non-syndromic cleft lip with or without a cleft palate. 


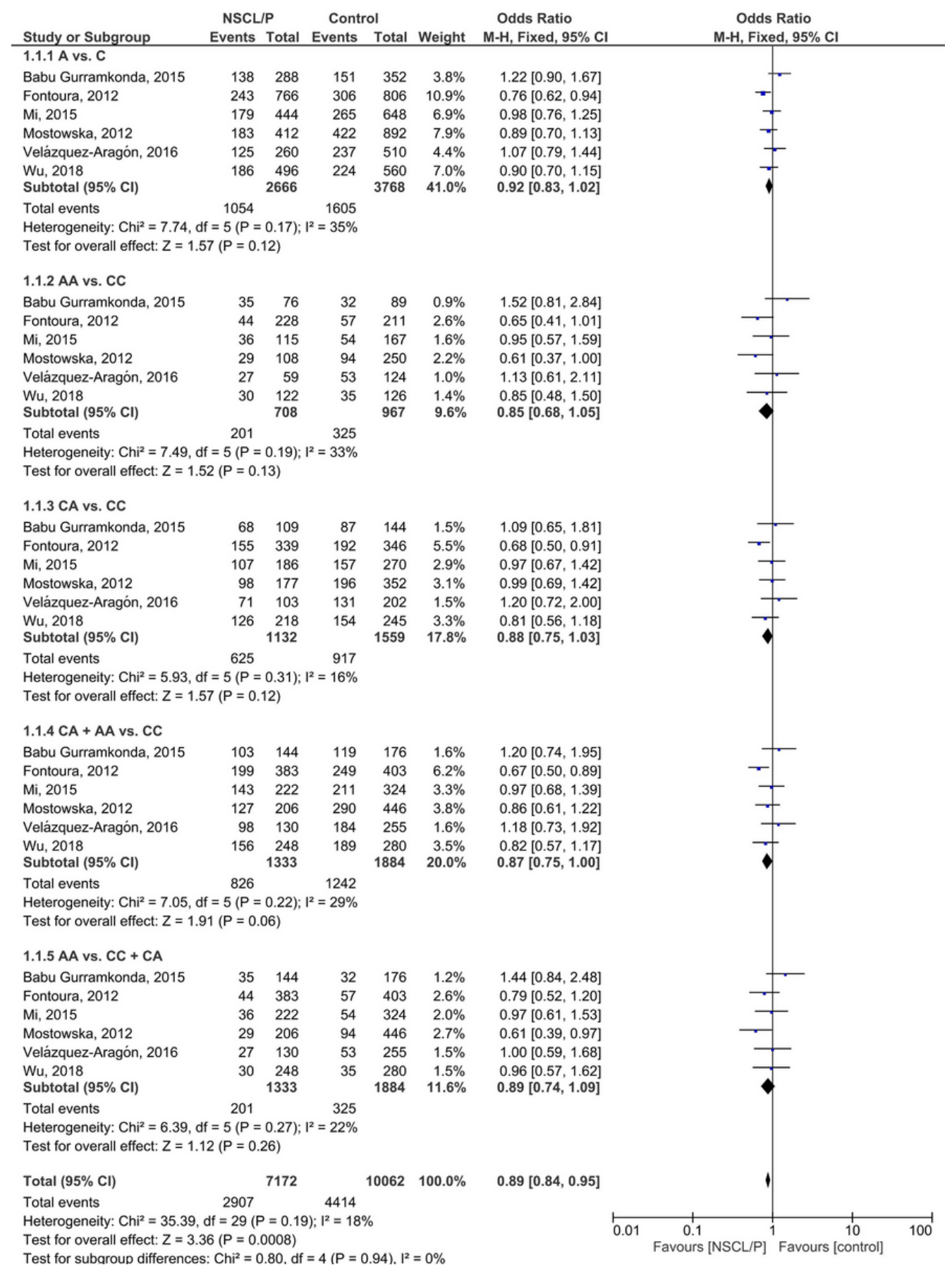

\section{Figure 3}

Forest plot of NSCL/P risk related to ABCA4 rs481931 polymorphism using the five genetic models. Abbreviation: NSCL/P, non-syndromic cleft lip with or without a cleft palate. 

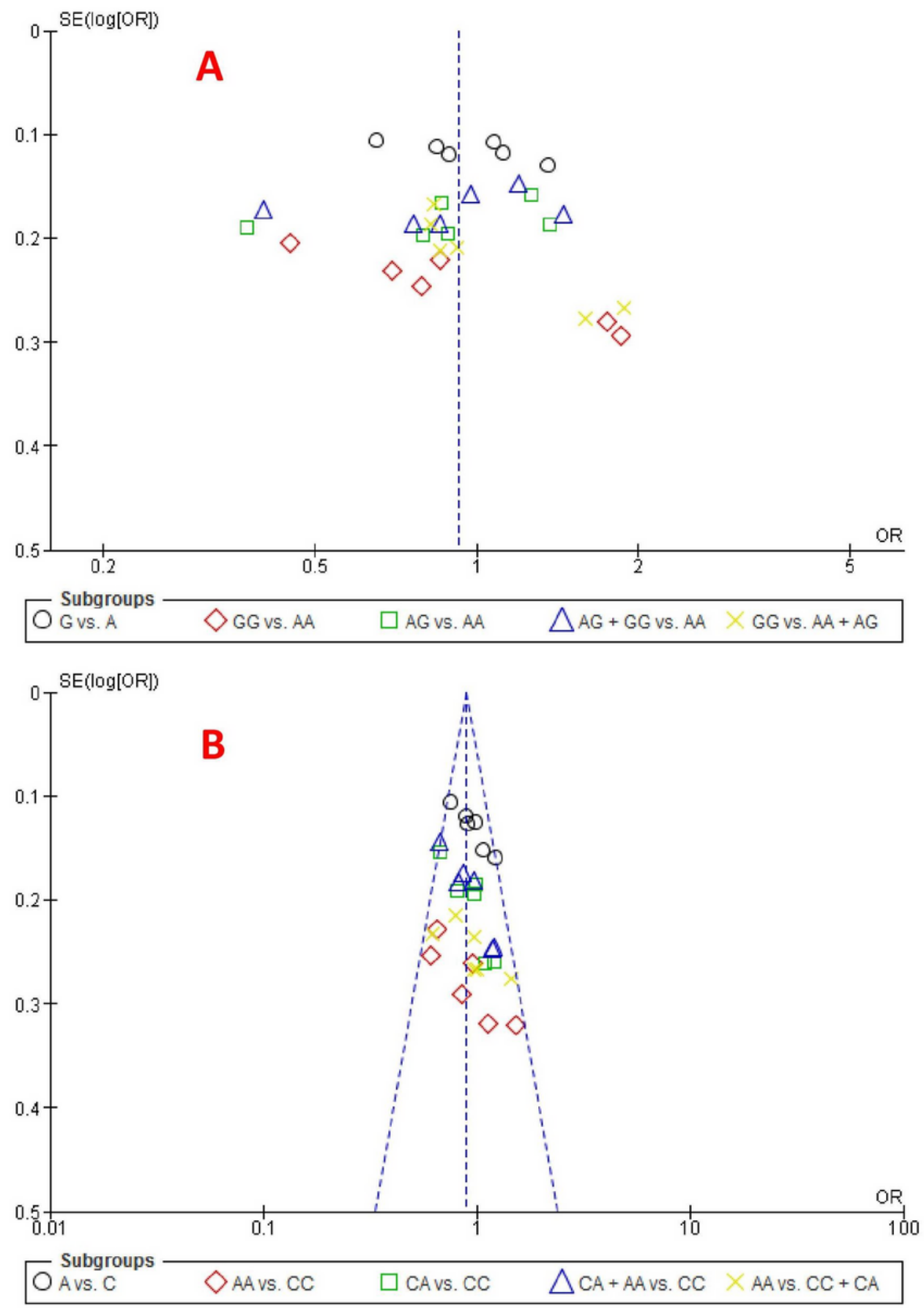

Figure 4

Funnel plot of the association between ABCA4 polymorphisms and risk of NSCL/P using the five genetic models: (A) rs560426 and (B) rs481931 